Jurnal Ekonomi Modernisasi

http://ejournal.unikama.ac.id/index.php/JEKO

JEM 12,3 (2016) 117-130

\title{
KAJIAN FENOMOLOGIS ANGGARAN BERBASIS KINERJA PADA RUMAH SAKIT BAPTIS BATU
}

\author{
Doni Wirshandono Yogivaria \\ Fakultas Ekonomika dan Bisnis Universitas Kanjuruhan Malang \\ Jl. S.Supriyadi No. 48 Malang \\ Alfinur \\ Fakultas Ekonomika dan Bisnis Univerirsitas Kanjuruhan Malang \\ Jl. S.Supriyadi No. 48 Malang
}

\begin{abstract}
This study aims to understand the performance based budgeting at the Hospital Private Sectors in batu. the subjects of this internship report consist of budgeting process included planning, performance measurement and evaluation, and reporting. besides, this internship also describes problems in budgeting process. because of qualitative research, data was set by natural condition. The technique of collecting data was done by observation, interview and documentation study. the result of data compiler was analyzed by using qualitative methods that developed based on descriptive paradigm. the approach of phenomenology analysis used to describes comprehensive. Findings of this research showed that in general, the idealism of performance based budgeting is achieved, although there is right in understanding of performance budgeting meaning by staff and managers. there are many in budgeting process sequences included planning.
\end{abstract}

Keywords: Qualitative, Phenomenology, Performance Based Budgeting

DOI : http://dx.doi.org/10.21067/jem.v12i3.1410

Diterima : Agustus 2016; Direvisi: September 2016; Diterima : Oktober 2016

\section{PENDAHULUAN}

Anggaran merupakan unsur penting dan proses perencanaan dan pengendalian yang digunakan untuk merencanakan berbagai aktivitas suatu pusat pertanggungjawaban agar pelaksanaan aktivitasnya sesuai dengan apa yang direncanakan. Bagi suatu departemen anggaran berfungsi sebagai alat perencanaan yang terdiri dari sejumlah target yang akan dicapai oleh manajer departemen untuk melakukan kegiatan tertentu di masa mendatang.

* Corresponding Author. doni.varia@gmail.com
Anggaran merupakan alat pengendalian manajer untuk melaksanakan kegiatan organisasi secara lebih efektif dan efisien. Anggaran dapat berfungsi sebagai alat pengendalian jika dalam penyusunannya melibatkan pihak-pihak yang terlibat dalam pelaksanaan anggaran. Pihakpihak yang dimaksud adalah atasan (principal) dan bawahan (agent). Salah satu wujud reformasi sistem penganggaran (budgeting reform) adalah penerapan Anggaran Berbasis Kinerja (Performance Based Budgeting). Sistem ini sudah menjadi trend perkembangan di banyak negara sejalan dengan budaya manajemen publik baru (Bambang Sancoko dkk, 2008). 
Beberapa penelitian terdahulu, Robinson (2002) menyebutkan prakondisi yang harus dimiliki untuk memberhasilkan implementasi performance based budgeting yaitu: (1) sistem informasi kinerja yg baik; (2) penyusunan indikator kinerja yg baik; (3) sistem akuntansi manajemen yg baik; (4) evaluasi dan alat analisis. Di Indonesia, penelitian tentang Penganggaran Berbasis Kinerja dilakukan oleh Sri Rahayu, dkk (2007) dengan pendekatan kualitatif untuk mengeksplorasi pemahaman atas fenomena penganggaran dengan berfokus bagaimana proses penyusunan anggaran pemerintah daerah pada tingkat satuan kerja perangkat daerah (SKPD) khususnya yang berkaitan dengan perilaku aparatur.

\section{TINJAUAN PUSTAKA}

\section{New Public Management (NPM).}

New Public Management (NPM) merupakan manajemen sektor publik yang berorientasi pada kinerja yang mempunyai beberapa konsekuensi, diantaranya adalah tuntutan untuk melakukan efisiensi, pemangkasan biaya (cost cutting) dan kompetisi. Tujuan NPM adalah mengubah administrasi yang sedemikian rupa sehingga administasi publik sebagai penyedia jasa bagi masyarakat harus sadar akan tugasnya untuk menghasilkan layanan yang efisien dan efektif, namun tidak berorientasi kepada laba (Osborne dan Gaebler, 1995). Langkah untuk menerapkan NPM bisa dilakukan dengan syarat didukung oleh birokrat, politisi dan masyarakat. Adapun perangkatperangkat adalah beberapa hal berikut ini

\section{Manajemen Kontrak.}

Manajemen kontrak adalah penyelenggaraan administrasi melalui kesepakatan-kesepakatan tentang tujuan yang hendak dicapai. Landasan manajemen kontrak adalah kontrak atau perjanjian antara pihak politisi (Parlemen atau DPR) dengan pihak yang akan memberikan layanan atau pemerintah sebagai pelaksana.

\section{Orientasi pada Hasil Kerja (Output).}

Administrasi hanya dapat dikendalikan secara efisien apabila titik tolak di dalam penyelenggaraannya berorientasi pada hasil (output) kerja.

\section{Controlling.}

Controlling diartikan sebagai satu konsep terpadu guna mengendalikan administrasi secara efisien dan ekonomis dalam rangka mencapai tujuan yang telah ditetapkan.

\section{Orientasi pada Pelanggan.}

Prinsip new public management menekankan bahwa "segala sesuatu yang tidak bermanfaat bagi pelanggan adalah pemborosan." satu tugas yaitu memberikan layanan kepada pelanggan yang memang berhak mendapatkannya. Ini artinya, pelanggan tidak dilihat sebagai abdi, melainkan sebagai pelanggan yang karena jasa yang dibayarkannya, mempunyai hak atas layanan dalam jumlah dan kuantitas tertentu, tetapi di lain pihak, dalam bidang-bidang tertentu memonopoli layanan jasa, dengan memberikan layanan dengan kualitas maksimal sejalan dengan benchmarking dan administrasi administrasi publik lainnya.

Tugas admistrasi adalah menciptakan transparansi dan tercapainya layanan, memberdayakan personil dalam melayani pelanggan, serta menciptakan kondisi yang berorientasi pada pelayanan.

\section{Personalia.}

Personalia merupakan faktor kunci bagi suksesnya sebuah proses modernisasi. Modernisasi administrasi publik hanya akan berhasil apabila potensi sumber daya manusia dimanfaatkan secara maksimal dan memperbaiki jika ada kekurangan. Proses modernisasi penting sekali melibatkan karyawan dengan menentukan tujuan-tujuan yang jelas dan menunjukkan keuntungan apa saja yang mereka miliki dengan tujuan yang jelas tersebut, meningkatkan kompetensi dan kualitas pegawai, di mana proses untuk menjadi karyawan dalam pelayanan publik harus berdasarkan kualifikasi dan reliabilitas.

\section{Teknik Informasi.}

Prinsip-prinsip manajemen yang telah diuraikan di atas serta berbagai bentuk pengendaliannya membutuhkan suatu sistem 
informasi yang sempurna. Penggabungan informasi dan komunikasi yang cepat, pemadatan data untuk pengendalian dan kemungkinan mengakses kumpulan data guna memenuhi keinginan pelanggan, membutuhkan jaringan alat pengolahan data sehingga pekerjaan bisa dilakukan dengan cepat, akurat dan dapat dipercaya.

\section{Manajemen Mutu.}

Manajemen mutu di sini adalah bahwa 'administrasi' melakukan segala sesuatu dalam rangka mengorganisir proses-proses produksi, standar dan sumber daya bersama para pegawai, tujuannya adalah merespon kebutuhan pelanggan.

\section{Penganggaran Berbasis Kinerja (Performance Based Budgeting).}

Sistem perencanaan anggaran pada saat ini telah mengalami perkembangan dan perubahan sesuai dengan dinamika manajemen sektor publik dan tuntutan yang muncul di masyarakat, yaitu sistem penganggaran dengan pendekatan New Public Management (NPM).

Kinerja adalah gambaran pencapaian pelaksanaan suatu kebijaksanaan dalam mewujudkan sasaran, tujuan, misi dan visi organisasi (Bastian, 2006). Menurut James B. Whittaker (1993) dalam Akuntansi Sektor Publik (Bastian 2006) dinyatakan bahwa Pengukuran/penilaian kinerja adalah suatu alat manajemen untuk meningkatkan kualitas pengambilan keputusan dan akuntabilitas.

Evaluasi kinerja merupakan proses penilaian dan pengungkapan masalah implementasi kebijakan untuk memberikan umpan balik bagi peningkatan kualitas kinerja. Cara pelaksanaan evaluasi dapat dilakukan dengan cara membandingkan hasil terhadap target (dari sisi efektivitas) dan realisasi terhadap pemanfaatan sumber daya (dilihat dari sisi efisiensi). Menurut Edwards (1980), empat faktor yang mempengaruhi keberhasilan Penjelasan ke empat faktor tersebut adalah sebagai berikut:

Komunikasi.

Kebijakan implementasi akan berjalan efektif apabila ukuran-ukuran dan tujuan-tujuan kebijakan dipahami oleh individu-individu yang bertanggungjawab dalam pencapaian tujuan kebijakan. Sumber informasi yang berbeda dapat melahirkan interpretasi yang berbeda pula. Agar implementasi berjalan efektif, siapa yang bertanggungjawab melaksanakan sebuah keputusan harus mengetahui apakah mereka dapat melakukannya.

\section{Sumberdaya.}

Komponen sumberdaya ini meliputi jumlah staf, keahlian dari para pelaksana, informasi yang relevan dan cukup untuk mengimplementasikan kebijakan dan pemenuhan sumber-sumber terkait dalam pelaksanaan program. Sumberdaya manusia yang tidak memadai (jumlah dan kemampuan) berakibat tidak dapat dilaksanakannya program secara sempurna karena mereka tidak bisa melakukan pengawasan dengan baik. Adanya manajemen SDM yang baik agar dapat meningkatkan kinerja program.

2. Disposisi atau sikap.

Salah satu faktor yang mempengaruhi efektifitas implementasi kebijakan adalah sikap implementor, jika implementor setuju dengan bagian-bagian isi dari kebijakan maka mereka akan melaksanakan dengan senang hati tetapi jika pandangan mereka berbeda dengan pembuat kebijakan maka proses implementasi akan mengalami banyak masalah.

Dukungan dari pejabat pelaksana sangat dibutuhkan dalam mencapai sasaran program. Wujud dari dukungan pimpinan ini diantaranya adalah menempatkan kebijakan menjadi prioritas program dan penyediaan dana yang cukup guna memberikan insentif bagi para pelaksana program agar mereka mendukung dan bekerja secara total dalam melaksanakan kebijakan/program.

3. Struktur Birokrasi.

Membahas badan pelaksana suatu kebijakan, tidak dapat dilepaskan dari struktur birokrasi. Struktur birokrasi adalah karakteristik, norma-norma dan pola-pola hubungan yang terjadi berulang-ulang dalam badan-badan eksekutif yang 
mempunyai hubungan baik potensial maupun nyata dengan apa yang mereka miliki dalam menjalankan kebijakan.

\section{Pengertian Badan Layanan Umum.}

Badan Layanan Umum adalah instansi yang dibentuk untuk memberikan pelayanan kepada masyarakat berupa penyediaan barang dan/ atau jasa yang dijual tanpa mengutamakan mencari keuntungan dalam melakukan kegiatannya didasarkan pada prinsip efisiensi dan produktivitas". Layanan Umum terbagi menjadi 3 kelompok, yaitu:

1. BLU yang kegiatannya menyediakan barang atau jasa meliputi rumah sakit, lembaga pendidikan, pelayanan lisensi, penyiaran, dan lain-lain.

2. BLU yang kegiatannya mengelola wilayah atau kawasan meliputi otoritas pengembangan wilayah dan kawasan ekonomi terpadu (Kapet).

3. BLU yang kegiatannya mengelola dana khusus meliputi pengelola dana bergulir, dana Usaha Kecil dan Menengah (UKM), penerusan pinjaman dan tabungan pegawai.

Karakteristik organisasi nirlaba berbeda dengan organisasi bisnis. Perbedaan utama yang mendasar terletak pada cara organisasi memperoleh sumber daya yang dibutuhkan untuk melakukan berbagai aktivitas operasinya. Organisasi nirlaba sumber daya dari sumbangan para anggota dan para penyumbang lain yang tidak mengharapkan imbalan apapun dari organisasi tersebut.

\section{Pedoman Akuntansi Badan Layanan Umum.} Pelaksanaan pengembangan dan penerapan sistem akuntansi Badan Layanan Umum yang mengacu pada standar akuntansi yang berlaku sebagaimana diatur dalam Peraturan Pemerintah Nomor 23 Tahun 2005 tentang Pengelolaan Keuangan Badan Layanan Umum, perlu diatur ketentuan mengenai pedoman akuntansi dan pelaporan keuangan Badan Layanan Umum. Berdasar pertimbangan hal inilah Menteri Keuangan Republik Indonesia menetapkan Peraturan Menteri Keuangan Nomor 76/PMP.05/2008 tentang Pedoman
Akuntansi dan Pelaporan Keuangan Badan Layanan Umum.

\section{Landasan Hukum Pengelolaan Keuangan Badan Layanan Umum.}

Penyelenggaraan fungsi organisasi Badan Layanan Umum berdasarkan kaidah-kaidah manajemen yang baik untuk memberikan layanan yang bermutu dan berkesinambungan, Pemerintah telah mengeluarkan Peraturan Perundang-Undangan mengenai Badan Layanan Umum yaitu : Peraturan Menteri Keuangan Nomor 76/PMK.05/2008 tentang Pedoman Akuntansi dan Pelaporan Keuangan Badan Layanan Umum; Dengan disahkan Peraturan Pemerintah (PP) Nomor 23 tahun 2005 tentang Pengelolaan Keuangan Badan Layanan Umum (BLU), maka status rumah sakit kini berubah menjadi Badan Layanan Umum.

Menurut Undang-Undang RI Nomor 44 tahun 2009, rumah sakit adalah Institusi pelayanan kesehatan yang menyelenggarakan pelayanan kesehatan perorangan secara paripurna yang menyediakan pelayanan rawat inap, rawat jalan, dan gawat darurat. Pelayanan kesehatan paripurna adalah pelayanan kesehatan yang meliputi promotif, preventif, kuratif, dan rehabilitatif.

Rumah sakit juga merupakan tempat menyelenggarakan upaya kesehatan yaitu setiap kegiatan untuk memelihara dan meningkatkan kesehatan serta bertujuan untuk mewujudkan derajat kesehatan yang optimal bagi masyarakat (Siregar dan Amalia, 2004).

\section{Tugas dan Fungsi Rumah Sakit.}

Berdasarkan keputusan Menteri

Kesehatan RI No. 983/Menkes/SK/XI/1992 tentang Pedoman Organisasi Rumah Sakit Umum, maka rumah sakit umum adalah rumah sakit yang memberikan pelayanan kesehatan yang bersifat dasar, spesialistik, dan subspesialistik. Berdasarkan Pedoman Organisasi Rumah Sakit Umum, maka rumah sakit umum mempunyai tugas melaksanakan upaya kesehatan.

Upaya kesehatan adalah setiap kegiatan untuk memelihara dan meningkatkan kesehatan yang bertujuan mewujudkan derajat kesehatan 
masyarakat secara optimal. Upaya kesehatan dilakukan dengan pendekatan pemeliharaan, peningkatan kesehatan (promotif), pencegahan penyakit (preventif), penyembuhan penyakit (kuratif), yang dilaksanakan secara serasi dan terpadu serta berkesinambungan (Siregar dan Amalia, 2004).

\section{METODE}

\section{Desain Penelitian.}

Data interview data dokumentasi Diskripsi hasil penelitian, hal-hal atau prospek baru yang ditemukan dari hasil penelitian Analisis dan Validasi Data Pertanyaan penelitian:

1. Bagaimana pemahaman pegawai tentang Penganggaran Berbasis Kinerja ?

2. Sejauh mana pelaksanaan Penganggaran Berbasis Kinerja di RS. Baptis Batu dan teori yg relevan?

Ada tiga pendekatan penelitian atau metode yang dapat digunakan yaitu kuantitatif, kualitatif, dan gabungan. Pendekatan kuantitatif disebut juga dengan pendekatan tradisional, positivisme, eksperimental, dan empiris.

Menurut Moleong (2005)," Penelitian kualitatif adalah penelitian yang bermaksud untuk memahami fenomena tentang apa yang dialami oleh subjek penelitian misalnya perilaku, persepsi, motivasi, tindakan, dan lain-lain secara holistik dengan cara deskripsi dalam bentuk kata-kata dan bahasa pada suatu konteks khusus yang alamiah dan dengan memanfaatkan berbagai metode yang alamiah. “

Pendekatan kualitatif dalam penelitian ini bertujuan untuk mendiskripsikan pemahaman atas fenomena penganggaran dengan berfokus bagaimana proses penyusunan anggaran pada satuan kerja Rumah sakit Baptis. Penelitian kualitatif tepat digunakan dalam studi ini karena mempertimbangkan nilai-nilai, budaya, norma, dan struktur organisasi dan juga faktor-faktor lainnya yang mendorong keberhasilan implementasi Penganggaran Berbasis Kinerja.

Penelitian yang peneliti pergunakan adalah penelitian kualitatif dengan pendekatan fenomenologi. Pendekatan Fenomenologi bertujuan memahami respon atas keberadaan manusia/masyarakat, serta pengalaman yang dipahami dalam berinteraksi (Saladien, 2006 dalam Sri Rahayu, 2007). Para fenomenolog percaya bahwa pada makhluk hidup, tersedia berbagai cara untuk menginterpretasikan pengalaman melalui interaksi dengan orang lain (Moleong, 2005: 18).

Pertimbangan digunakannya pendekatan fenomenologi adalah bahwa proses penganggaran merupakan suatu fenomena sosial yang disusun dengan adanya interaksi social antara berbagai pihak. Pendekatan fenomenologi lebih mudah apabila berhadapan dengan kenyataan karena menyajikan secara langsung hubungan antara peneliti dan informan, dan lebih dapat menjelaskan terhadap fenomena yang ada serta pola-pola nilai yang dihadapi.

Pedoman untuk wawancara dan observasi yang dibuat khusus pada penelitian ini digunakan untuk memperoleh data tentang gambaran secara umum penerapan Penganggaran Berbasis Kinerja di Rumah sakit Baptis.

\section{Alasan Pemilihan Setting.}

Penelitian tentang Penganggaran Berbasis Kinerja ini menarik karena peneliti merasakan bahwa pelaksanaan anggaran berbasis kinerja pada pelayanan publik yang berlatar belakang swasta masih jarang didalam khasanah penelitan Penganggaran Berbasis Kinerja.

Informasi pendahuluan yang diperoleh, yaitu dari RS. Baptis, mengalami perubahan yang signifikan ketika pelaksanaan anggaran dilakukan sesuai perencanaan. Pertimbangan lain karena RS memiliki keunikan dengan karakteristik yang berbeda ini tentu saja akan membuat Rumah Sakit menjadi dasar penelitan dimana letak keunikan didalam mengelola anggaran dan menilai kinerjanya.

\section{Metode Pengumpulan Data.}

Lofland (1984) dalam Moleong (2005) mengatakan, sumber data utama dalam penelitian kualitatif adalah kata-kata dan tindakan, Untuk memperoleh gambaran yang lebih mendalam, holistik, terhadap implementasi Penganggaran Berbasis Kinerja di Rumah sakit, maka penelitian ini menggunakan metode sebagai berikut: 


\section{Teknik Analisis.}

Analisis data adalah proses mengatur urutan data, mengorganisasikannya ke dalam suatu pola, kategori dan satuan uraian dasar. Analisis data merupakan langkah terakhir penelitian sebelum melakukan penarikan suatu kesimpulan.

Analisis data ini terdiri dari:

1. Data dari wawancara, observasi dan dokumentasi diorganisir kesamaan dan perbedaannya sesuai dengan pertanyaan penelitian.

2. Data yang sudah diorganisir ditentukan temanya.

3. Mencari keterkaitan antar tema.

4. Interpretasi atas temuan sesuai dengan keterkaitan antar tema dengan menggunakan teori yang relevan.

5. Hasil interpretasi dituangkan dalam deskriptif analitik kontekstual

\section{HASIL DAN PEMBAHASAN}

Berdasarkan latar belakang dan rumusan masalah, kajian teori dan metodologi penelitian yang telah diuraikan terdahulu, maka pada subbab ini akan disajikan hasil penelitian melalui wawancara langsung dengan informan yang telah dipilih. Informan tersebut adalah para pimpinan maupun staf yang terkait langsung dengan penganggaran di Rumah Sakit Baptis Batu. Hal ini untuk menjamin validitas informasi yang disampaikan. Dari data wawancara, data dokumentasi dan observasi langsung yang diperoleh dilakukan. Selanjutnya dilakukan pemahaman untuk menemukan tema yang ada. Untuk menjawab pertanyaan penelitian pertama yaitu "Bagaimana pemahaman pegawai tentang Penganggaran Berbasis Kinerja

\section{Pemahaman Makna Penganggaran Berbasis Kinerja.}

Ciri utama Performance Based Budgeting adalah anggaran yang disusun dengan memperhatikan keterkaitan antara pendanaan (input) dan hasil yang diharapkan (outcomes). Secara umum pegawai di Rumah Sakit Baptis Batu sudah mengerti makna Penganggaran Berbasis Kinerja. Hal ini terbukti dari wawancara dengan beberapa pejabat maupun staf di lingkungan Rumah Sakit Baptis Batu, diantaranya dengan DW bagian keuangan, yang mengatakan :

" Secara singkat saja yang jelas kegiatan yang dibebankan pada anggaran jelas outputnya.."

Pendapat yang tidak jauh berbeda juga diutarakan oleh PS selaku Staf Akuntansi Rumah Sakit Baptis Batu, berikut petikannya:

"Pengangaran Berbasis Kinerja menurut saya suatu organisasi punya anggaran tapi pemakaian dana itu betul-betul yang ada kinerjanya."

Hal yang senada juga dinyatakan oleh BS, Kepala Bagian Keuangan. Dalam wawancaranya beliau mengatakan:

"Penganggaran Berbasis Kinerja mestinya ya penganggaran yang ada outputnya, kemudian ada data dukungnya, masing-masing kegiatan ada sasarannya."

Pendapat beberapa pegawai tersebut di atas telah sesuai dengan definisi Performance Based Budgeting (Penganggaran Berbasis Kinerja) yaitu sistem penganggaran yang berorientasi pada'output' organisasi dan berkaitan sangat erat dengan Visi, Misi dan Rencana Strategis organisasi (Haryanto, Sahmuddin, Arifuddin: 2007).

\section{Implementasi Penganggaran Berbasis Kinerja.}

Pada dasarnya pegawai bagian front office (Kantor) mengetahui makna Penganggaran Berbasis Kinerja, dan sistem penganggaran ini sudah dilakukan secara benar. Hasil penelitian pelaksanaan Penganggaran Berbasis Kinerja di Rumah Sakit Baptis batu ini akan diuraikan dalam tahapan-tahapan sebagai berikut:

\section{Perencanaan Kinerja.}

Perencanaan kinerja merupakan dasar bagi penerapan anggaran berbasis kinerja. Indikator-indikator kinerja dirumuskan dan ditetapkan sesuai dengan informasi kinerja yang 
diinginkan oleh organisasi. Informasi kinerja yang terdapat dalam perencanaan kinerja merupakandasar alokasi anggaran berbasis kinerja. Dalam sistem Penganggaran Berbasis Kinerja ini, manfaat perencanaan kinerja adalah sebagai berikut: (1). Menghubungkan perencanaan strategis dan perencanaan operasional secara terinci. (2). Membantu pencapaian hasil pelaksanaan program. (3). Memudahkan proses pengukuran dan penilaian kinerja. (3). Membantu dalam menetapkan target kinerja. (4). Membantu pemantauan dan evaluasi kinerja

Penyusunan rencana kerja di rumah Sakit Baptis batu bersifat kebiasaan didalam menyusun rencana kerja disesuaikan dengan kebutuhan yang terjadi. Hal ini tersampaikan didalam wawancara dengan Direktur Rumah Sakit Baptis Batu dalam wawancara dengan dr. ARP selaku Direktur dimana penyusunan rencana kerja dilakukan terlebih dahulu baru disambungkan dengan Rencana Strategis yang ada, berikut petikannya:

"RSB (Rencana Strategi Bisnis). Dari tahun ke tahun yang dituangkan didalam TOR (Acuan kerja organisasi) selalu dihubungkan dengan rencana strategis Rumah Sakit Baptis Batu"

Hal yang serupa juga dinyatakan oleh PS, bagian Akuntansi yang mengatakan:

"Arahan sudah jelas dan setiap bulannya antara bagian mengecek berapa anggaran yang telah dikeluarkan setiap bulannya, yaitu harus mengacu pada TOR. kegiatan dicari hubungannya dengan renstra dan berapa persen yang tercapai dan belum tercapai. Demikian juga pencapaian kinerja pada renstra dievaluasi tiap tahun yang mestinya sangat penting untuk perencanaan tahun berikutnya."

Menyimak fenomena di atas ada sesuatu hasil positif yang dapat dilihat dari hasil kerja baik secara keuangan maupun kegiatan Rumah Sakit baptis Batu, pembuatan anggaran di Rumah Sakit Baptis Batu mempertimbangkan atas capaian kinerja renstra (rencana strategis) pada tahun sebelumnya.
Sasaran dan Program yang telah ditetapkan dalam Rencana Strategis dengan berpedoman pada renstra, perencanaan anggaran menjadi terpantau. Rumah Sakit Baptis Batu mempunyai dua tipikal unit kerja, dimana Instalasi merupakan unit kerja yang bisa menghasilkan pendapatan atau penerimaan yang disebut busines division dan yang lain adalah unit kerja berupa bagian yang disebut juga Support Division,

Pada tahun 2008 Rumah Sakit Baptis Batu memulai Renstra dan Pejabat Kepala Bagian Keuangan Rumah Sakit Baptis Batu, dalam kutipannya mengatakan:

"Sebelum adanya Rencana Strategis dan TOR oleh unit kerja sering terjadi anggaran belanja lebih besar dari anggaran pendapatan, tetapi setelah tiap unit membuat rencana kerja TOR anggaran belanja lebih bisa dikendalikan dan pencapaian pendapatan dapat terkendali."

Proses penentuan pendapatan juga di rencanakan dengan, Unit dan instalasi yang bersangkutan. Pendapatan harus diperkirakan sesuai plafon anggaran dapat ditentukan sebelum unit kerja mengajukan usulan anggarannya. Penentuan anggaran belanja dimulai dengan perhitungan target pendapatan yang rencana anggaran belanja yang tepat.

\section{Pelaksanaan Anggaran.}

Pelaksanaan anggaran merupakan proses merealisasikan apa yang sudah direncanakan dalam dokumen perencanaan. Pelaksanaan anggaran erat kaitannya dengan Rencana Acuan Kerja ( RAK ) dan Standar Operasional Prosedur (SOP). SOP merupakan langkah operasional untukmenyelesaikan suatu tugas dengan cepat, tepat dan efektif. Sedangkan Rencana Acuan Kerja ( RAK ) adalah yang memuat bagaimuan unit itu bekerja didalam satu tahun berjalan dan indikator kinerja. Standar Pelayanan Minimal (SPM) dan Standar Operasional Prosedur (SOP) merupakan elemen yang harus ditentukan sebelum melaksanakan Penganggaran Berbasis Kinerja. SPM dan SOP tersebut terutama yang menyangkut Tugas pokok dan Fungsi (tupoksi) setiap unit kerja. Tupoksi menjabarkan rencana 
kerja dasar suatu unit kerja. Anggaran menjabarkan bagaimana unit kerja akan mengalokasikan sumberdaya yang dimiliki untukmelaksanakan tupoksinya.

Wawancara mengenai SPM dan SOP dengan YSW, Bagian Administrasi Rumah Sakit Baptis Batu mengatakan:

“ SPM dan SOP, suatu kegiatan dari seluruh yang dikerjakan oleh karyawan maka SPM dan SOP wajib dibuat oleh Kepala Bagian dan Kepala Instalasi."

Wawancara dengan YSW tersebut dapat diketahui bahwa RSBB mempunyai SPM dan SOP berdasarkan tupoksi yang sudah ditetapkan. SPM dan SOP ini ditetapkan sesuai dengan ukuran kinerja bagi setiap tugas pokok dan fungsi maupun kegiatan-kegiatan tambahan. Standar Operasional Prosedur ini digunakan sebagai acuan dalam pelaksanaan

Penganggaran Berbasis Kinerja. Hal ini sesuai dengan penelitian M. Aris Firmansyah (2008) dimana faktor diskripsi kerja merupakan salah satu faktor yang mempengarui perencanaan Penganggaran Berbasis Kinerja. Wawancara lebih jauh dengan YSW, ditemukan informasi lain mengenai pelaksanaan anggaran yang menuju maksimal. Ketika ditanyakan pelaksanaan Penganggaran Berbasis kinerja di RSBB, beliau mengatakan:

"Saya kira teman-teman kepala bagian dan kepala unit mengarah ke sana, karena antara perencanaan yang dituangkan secara tertulis hampir sama dengan pelaksanaannya walaupun ada kendala-kendala itu hal biasa didalam suatu organisasi."

\section{Pengukuran Kinerja.}

Pengukuran kinerja disebut juga proses

yang obyektif dan sistematis dalam mengumpulkan, menganalisa dan menggunakan informasi untuk menentukan seberapa efektif dan efisien suatu kegiatan dan sasaran yang dicapai. Untuk bisa mengukur seberapa efektif suatu program dan kegiatan terlebih dahulu harus mendefinisikan outcome (hasil) dari program yang ingin dicapai. Langkah selanjutnya yaitu mengukur kinerja program yang berkaitan dengan pencapaian hasil yang diinginkan serta melaporkan hasil kepada para pengambil keputusan berdasarkan informasi yang diberikan. Pengukuran kinerja ini untuk menilai keberhasilan atau kegagalan suatu unit kerja.

Dalam hal pengukuran kinerja ini, SM, Bagian SDM, dalam wawancara mengatakan:

"Setiap organisasi kepala unitnya membuat KPI Key Performance Indikator setiap pegawai yang diselaraskan dengan seluruh kegiatan dalam unit tersebut sesuai dengan Job masing-masing individu".

\section{Evaluasi Kinerja.}

Evaluasi kinerja adalah kegiatan untuk menilai atau melihat keberhasilan dan kegagalan manajer publik dalam kegiatan dan fungsi yang diamanahkan kepadanya sebagaimana visi dan misi organisasi. Hasil evaluasi kinerja dapat memberikan informasi tentang keberhasilan dan kegagalan program serta kegiatan pada suatu unit kerja atau organisasi. Proses anggaran merupakan kesempatan yang baik untuk melakukan evaluasi apakah didalam melakukan tugasnya secara ekonomis, efektif dan efisien. Hal ini tidak mudah untuk dipenuhi untuk sebuah rumah sakit.

Hal-hal yang salah dapat dilakukan dengan cara yang salah selama bertahun-tahun tanpa adanya evaluasi. Diperbaiki dengan membuat evaluasi setiap bulan yang ditampilkan saat rapat kerja unit dan instalasi Dalam wawancara dengan PS bagian akuntansi, mengatakan:

"Suatu kegiatan dikerjakan secara unit , diperhitungkan efisiennya, bahkan kegiatan dilakukan dimana jumlah yang dilakukan harus ada pembandingnya di tahun sebelumnya."

Hasil wawancara di atas menggambarkan Rumah Sakit Baptis Batu melaksanakan evaluasi kinerja. Wawancara tersebut juga memperkuat temuan mengenai adanya evaluasi atas efisiensi dan efektifitas kegiatan yang diusulkan. Indikator kinerja yang dibuat berbeda antara satu 
unit dengan unit yang lain meskipun karakteristik kegiatannya sama, sehingga mengindikasikan adanya patokan (bencmarking) dalam perencanaan anggaran yang dibuat. Dengan demikian pembuat anggaran diberi kebebasan dalam menentukan indikator kinerjanya sendiri yang tentu saja akan menghasilkan indikator yang mudah untuk dicapai. Kondisi ini diperkuat oleh SM bagian SDM, yang mengatakan:

"Teman-teman berupaya untuk mengevaluasi didalam rapat kerja dan memberikan masukan, ramai sih terkadang ada yang tidak terima dengan masukkannya akan tetapi kritik yang membangun adalah baik untuk kemajuan unit kerja masing-masing kan. Evaluasi kinerja bukan hanya sebatas serapan keuangan saja tetapi juga memperhatikan segi efektifitas, ekonomis, efisiensi maupun manfaat dari kegiatan yang dilaksanakan."

Implementasi Penganggaran Berbasis Kinerja di RSBB juga ditemukan mengenai sistem kontrol yang berjalan dengan baik. Kondisi ini dinyatakan oleh PS bagian akuntansi, yang mengatakan:

"Saya berpikir terkadang tidak masuk akal, karena antara perencanaan dengan pelaksanaan mendekati padahal menurut saya perkiraan anggaran itu terkadang diluar anganangan. Kebijakan memang bisa berubah pada saat pelaksanaan, tetapi ke arah yang positif Rumah Sakit Baptis Batu memang menunjuk bagian akuntansi untuk mengawal dan mengawasi segala bentuk pelaksanaan anggaran, itulah yang membuat terkadang bagian akuntansi sendiri bingung kok bisa ya anggarannya dapat tercapai."

Hal ini menginformasikan bahwa Rumah Sakit Baptis Batu menempatkan bagian akuntansi diposisi yang tepat dalam melakukan evaluasi anggaran. Dari beberapa wawancara di atas menggambarkan kekuatan evaluasi kinerja di Rumah Sakit Baptis Batu berjalan dan terus beriringan dengan proses anggaran. Hasil penelitian ini sama dengan hasil penelitian Wang (1999) dalam penelitiannya menghasilkan bahwa implementasi sistem tergantung dari beberapa faktor penting diantaranya kesepakatan ukuran kinerja dan evaluasi dari semua pihak. Robinson (2002) menyebutkan prakondisi yang harus dimiliki untuk memberhasilkan implementasi performance based budgeting yaitu: (1) sisteminformasi kinerja yg baik; (2) penyusunan indikator kinerja yg baik; (3) sistem akuntansi manajemen yg baik; (4) evaluasi dan alat analisis.

\section{Pelaporan Kinerja.}

Laporan kinerja yang disusun berupa Laporan Akuntabilitas Kinerja Instalasi atau bagian yang dibuat bulan Januari untuk menilai seluruh kinerja instalasi atau bagian tahun sebelumnya. Rumah Sakit Baptis Batu sudah membuat laporan kinerja yang berupa laporan Evaluasi didalam laporan Rencana Acuan Kerja (RAK). Laporan kinerja ini dibuat oleh masingmasing unit kerja dan dikompilasi di tingkat Rumah Sakit Baptis Batu oleh Bagian Administrasi SO, Bagian Administrasi mengatakan:

"Laporan kinerja telah disusun dengan baik, format juga disamakan sehingga mudah untuk dibuat evaluasi."

Pernyataan tersebut diperkuat oleh dr. IET, Wadir Umum Keuangan, yang menuturkan:

"Sejak Rumah Sakit Baptis Batu diminta menyusun Laporan Akuntabilitas Kinerja di bagian masing-masing, penganggaran sudah didasarkan atas kebutuhan unit dan instalasi yang menggembirakan lagi Kepala unit kerja dan Instalasi mengerjakan itu seperti unit dan instalasi yang mereka pimpin seperti perusahaannya sendiri, Evaluasi yang dibuat akhirnya sinkron dengan penganggaran."

Dari wawancara di atas mengungkapkan bahwa evaluasi kinerja dibuat untuk untuk acuan kinerja tahun berikutnya. Laporan Kinerja yang dibuat dievaluasi atas pencapaian kinerjanya.

Pernyataan diatas diperkuat dengan pendapat YSW, bagian administrasi 
diwawancarai tentang Laporan pertanggung jawaban kinerja mengatakan:

"O..sudah pak, Laporan pertanggungjawaban kinerja yang disusun sudah sesuai dengan perencanaan dan sudah dievaluasi prosentase pencapaiannya."

Setelah ditelusuri dokumen buku laporan hasil kinerja memang sudah dilakukan.

Implementasi Penganggaran Berbasis Kinerja bisa dilakukan di Rumah Sakit Baptis Batu Implementasi Penganggaran Berbasis Kinerja yang sesuai harapan di Rumah Sakit Baptis Batu disebabkan oleh berbagai prakondisi yang menjadi keberhasilan. Dari hasil penelitian, berbagai keberhasilan yang ditemukan dalam implementasi Penganggaran Berbasis Kinerja di RSBB adalah sebagai berikut :

Komunikasi.

Implementasi akan berjalan efektif apabila ukuran-ukuran dan tujuan-tujuan kebijakan dipahami oleh individu-individu yang bertanggungjawab dalam pencapaian tujuan kebijakan. Kejelasan ukuran dan tujuan kebijakan dengan demikian perlu dikomunikasikan secara tepat dengan para pelaksana.

Komunikasi dalam bentuk sosialisasi dan pelatihan di Rumah Sakit Baptis Batu mengenai Penganggaran Berbasis Kinerja juga dilakukan. Hal ini dapat dilihat dari wawancara dengan EB selaku bagian diklat, berikut petikannya:

"Kalau itu memang dari pimpinan tidak bosan untuk mengingatkan tentang evaluasi dan tolak ukur kinerja, kemudian seringnya sosialisasi untuk penyegaran kembali."

Hal yang serupa juga dinyatakan oleh PS, bagian akuntansi mengatakan:

"SDM saya kira pelatihan-pelatihan secara periodik sudah dilaksanakan, sehingga perencanaan dan pelaksanaan akan nyambung. Selama ini anggaran berbasis kinerja memang tidak semata-mata seperti yang mas sebutkan ini tetapi pada kenyataannya kalau berbicara evaluasi-evaluasi, ayo buat anggaran-anggaran ya seluruh kepala unit tahu itu mas."
Dari wawancara di atas menunjukkan bahwa sosialisasi sudah proaktif dilaksanakan. Sosialisasi disebabkan karena pimpinan maupun staf sudah memahami betul teknis pelaksanaan sistem penganggaran ini. Hal ini terungkap dalam wawancara dengan dr. APR Direktur Rumah Sakit Baptis Batu, Dalam wawancaranya beliau mengatakan:

"Yang pertama jangan jenuh-jenuh untuk mengajak kaunit sama kainstal Penganggaran Berbasis Kinerja ini, yang kedua dibikin format teknis yang merujuk pada kegiatan yang ada, yang ketiga SOP harus jelas, yang keempat komitmen dari pimpinan unit."

Arahan pimpinan memegang peranan penting dalam mencapai keberhasilan suatu program dan kebijakan. Keberhasilan implementasi Penganggaran Berbasis Kinerja ini sangat memerlukan arahan yang jelas dari pimpinan, baik itu pimpinan level atas, menengah maupun level bawah. Dalam wawancara dengan PS bagian akuntansi, berikut petikannya:

"Pimpinannya mendukung mas kebetulan pimpinan saya $d r$. APA sangat mendukung. Kemarin kita nyusun balance score card untuk membuat renstra tahun 2013-2017 saja yang menjadi mentoring langsung direktur. SPM bukan sekedar ditulis tetapi kegiatan kita setiap unit itu ada mas jadi SPMnya banyak. monitoring dari pimpinan langsung."

Hal ini juga dimintakan konfirmasi kepada BS, bagian keuangan, beliau mengatakan:

"yang saya ketahui sangat komplek sekali terutama yang ada dari masing-masing unit jelas, kemudian dipahami oleh temen-temen jelas kita sendiri juga belajar, arahan-arahan dari pimpinan. Pimpinan semangatnya tinggi dan temen-temen jelas, melihat arahanarahannya, perencanaan konsisten policy pimpinan jelas."

Dari informasi yang telah diuraikan diatas menunjukkan kebijakan yang komplek 
membutuhkan kerjasama banyak orang. Unsur yang mungkin berpengaruh terhadap suatu organisasi dalam implementasi kebijakan diantaranya tingkat pengawasan hierarkhis terhadap keputusan-keputusan sub unit dan proses-proses dalam badan pelaksana. Sesungguhnya implementasi kebijakan diterima oleh semua personil dan mengerti secara jelas dan akurat mengenai maksud dan tujuan kebijakan.

\section{Sistem Penghargaan (Reward) dan Sanksi (Punishment).}

Penghargaan (reward) dan sangsi (punishment) merupakan faktor yang sangat penting untuk meningkatkan kinerja pada organisasi publik, bagaimana bentuk reward and punishment ini untuk dituangkan dalam lembaga bisa langsung dan nyata pengelolaan keuangannya betul-betul bias efektif berjalan. Sistem reward and punishment ini mulai diterapkan secara jelas di RSBB.

Hal ini tersirat dalam wawancara dengan SW, Bagian SDM yang mengatakan:

"Di Rumah Sakit ini hanya ada dua pekerjan, satu terkait dengan pelayanan Instalasi dan kedua tidak terkait pendukung pelayanan Support Division atau Back office. Akan tetapi kedua bagian ini saling berkaitan dan menerima penghargaan buat hasil jerih payah mereka yaitu tambahan uang transport dan bonus ya seperti remun tapi perhitungannya masih dibuat patokan akan tetapi ada tambahan bagi karyawan ditempat ini."

Kondisi ini diperkuat oleh pernyataan dr. APA, Direktur RSBB, dalam wawancara mengatakan:

"Reward \& punisment pasti kita memberi ada yang tidak puas pasti ada, akan tetapi tujuan dari manajemen adalah kepuasan pegawai yang ingin kita penuhi. Kita melihat kemampuan dan kinerja masing-masing. Untuk yang kinerjanya baik pasti ada perbedaan dengan pegawai yang kinerjanya biasa-biasa."
Dari beberapa wawancara tersebut mengindikasikan bahwa sistem reward and punishment yang dipahami di RSBB sudah dipahami. Akan tetapi untuk keberhasilan implementasi penganggaran berbasis kinerja ini tentu saja lebih banyak menyangkut kinerja organisasi/unit kerja. Penghargaan dan sangsi atas kinerja unit kerja juga mengarah untuk diterapkan di RSBB.

Hal tersebut dapat dilihat dari pernyataan Direktur RSBB dr. APR, yang mengatakan:

"adalah perhatian kita untuk tim atau unit memang saat ini masih belum berbicara nominalnya berapa akan tetapi Tim yang terpilih karena baiknya pelayanan unit mereka, dapat hadiah dari Tim Super Service makan bersama Direktur, Tim itu bisa memilih dimana saja restoran yang mereka senang dan apabila ada karyawan yang memperoleh penilaian tertinggi dalam satu tahun karena terpilih menjadi karyawan dengan kinerja yang baik versi Tim Super Service akan mendapat hadiah liburan bersama keluarga ditambah uang saku."

Rumah Sakit Baptis Batu membuat langkah penilaian kerja dari berbagai aspek yang bertujuan untuk meningkatkan kualitas kinerja pegawainya. Reward dan punishment merupakan motivasi bagi unit kerja dalam pelaksanaan anggaran. Tanpa adanya motivasi, bekerja menjadi hampa. Efek negatifnya bekerja menjadi lambat selesai, sering meleset dari target waktu yang telah ditentukan dan tidak efektif.

Reward dan punishment untuk kinerja unit/organisasi dapat berupa penambahan atau pengurangan insentif atau bonus untuk tahun yang akan datang. Dengan adanya reward dan punishment ini unit kerja/organisasi akan termotivasi untuk mewujudkan capaian kinerjanya. Pentingnya sistem reward and punishment ini sesuai dengan teori implementasi kebijakan Edwads III dimana sikap yang berupa dukungan dari pejabat pelaksana sangat dibutuhkan dalam mencapai sasaran program.

Wujud dari dukungan pimpinan ini diantaranya adalah menempatkan kebijakan menjadi prioritas program dan penyediaan dana yang cukup guna memberikan insentif bagi para 
pelaksana program agar mereka mendukung dan bekerja secara total dalam melaksanakan kebijakan/program. Untuk itu RSBB ke depan harus meningkatkan system rewards and punishment ini sesuai dengan kesepakatan bersama.

Untuk menerapkan reward dan punishment ini perlu adanya penetapan kinerja bagi masing-masing unit kerja. Penetapan Kinerja merupakan pernyataan komitmen yang merepresentasikan tekad dan janji untuk mencapai kinerja yang jelas dan terukur dalam rentang waktu satu tahun.

Penetapan Kinerja disepakati bersama antara pengemban tugas dengan atasannya (Performance Agreement). Penetapan Kinerja juga merupakan ikhtisar Rencana Kinerja Tahunan yang telah disesuaikan dengan ketersediaan anggarannya, yaitu setelah proses anggaran (budgeting process).

\section{Etika Kerja.}

Etika kerja terkait dengan apa yang seharusnya dilakukan karyawan atau manajer. Terkait etika kerja ditemukan adanya etika kerja yang mengarah pada peningkatan kualitas kinerja di RSBB. Hal tersebut terungkap dari wawancara dengan DB, Ketua Komite keperawatan yang mengatakan:

"Hmmmm... budaya kerja di RSBB sudah terbentuk dengan budaya yang... nuwun sewu (minta maaf)... ingin enak-e dewe (ingin seenaknya sendiri) akan tetapi setelah rencana acuan kerja diperkenalkan kepada Kepala unit kerja sekitar tahun 2009 mulai tertata hirarki yang ada tidak ada yang merasa senior tetapi saling mengisi sesuai dengan job diskripsion mereka."

Ketika ditanyakan di level pimpinan, pendapat yang serupa dinyatakan oleh dr. APR, Direktur Rumah Sakit Baptis Batu. Dalam pernyataannya beliau mengatakan:

"SDM penting perlu dipacu dengan cara-cara baru. Ini suatu perubahan yang awalnya seorang pegawai dalam melakukan aktifitas monoton, harus dirubah sikapnya awalnya susah tapi sekarang kemajuannya pesat saya hanya melihat dan merasa senang karena itu juga meringankan pekerjaan seorang pimpinan."

Dalam rangka memantapkan etika kerja, hal mendasar yang perlu ditegaskan adalah soal job description. Job description yang dimaksud disini yaitu berupa tugas pokok dan fungsi. Masing-masing pegawai harus paham secara baik apa saja yang menjadi tugas pokok dan fungsinya (tupoksi). Tupoksi harus dikerjakan lebih dahulu baru kemudian mengerjakan tugastugas tambahan yang dibebankan. Jangan sampai seorang pegawai menjadi sangat sibuk tetapi tidak mengerjakan pekerjaan pokoknya.

Tupoksi yang telah dijabarkan dalam Standar Operational Procedurs (SOP) maupun Standar Pelayanan Minimal (SPM) masingmasing unit kerja memiliki yang sesuai dengan kebutuhan organisasi dan ditetapkan oleh Direktur RSBB. Dalam wawancara dengan SM, Staf Adm, menuturkan tentang SOP sebagai berikut:

" Teman-teman berusaha untuk menyelaraskan SOP-SOP dengan kegiatan dan aturan yang ada sehingga segala pekerjaan dapat diperhitungkan secara efisien dan sesuai dengan keperluan unit tersebut."

Dengan tugas dan fungsinya yang sudah ditetapkan, pegawai diharapkan memahami tupoksinya masingmasing, sehingga dalam melaksanakan kegiatan dapat berjalan dengan baik. Hal ini dinyatakan oleh EW, staf SDM yang mengatakan:

"Selama ini unit membuat kegiatan dievaluasi atas efektifitas kegiatan tersebut, dan setiap unit mencari solusi jalan pemecahannya apabila anggaran melebihi dari yang telah dianggarkan."

Dari wawancara tersebut kecenderungan pegawai untuk mengerjakan kegiatan-kegiatan yang berhubungan dengan organisasinya. Di sinilah tugas seorang atasan harus senantiasa memberikan arahan-arahan dan memacu pegawai yang menyangkut tugas pokok dan 
fungsi pegawai yang bersangkutan. Berdasarkan analisis tersebut di atas, maka ada beberapa langkah yang dapat ditempuh oleh Rumah Sakit Baptis Batu yaitu : (1). Membuat budaya kerja yang baik dan etos kerja yang sehat adalah sulit, apabila arah kinerja telah baik tugas sebuah organisasi mencari terobosan-terobosan baru yang membuat unit/organisasi, pegawai/individu merasa betah untuk melakukan segala tugas yang diberikan oleh atasan. (2). Monitoring, pengendalian dan arahan dari pimpinan terkait pelaksanaan acuan kerja yang ditetapkan terus dilaksanakan pencapaian efektifitas dan efisiensi menjadi tujuan utama dari organisasi. (3). Pemimpin harus selalu ditingkatkan didalam kompetensi dan pendidikan-pendidikan organisasi untuk memperkokoh organisasi dan peningkatan pelayanan.

\section{KESIMPULAN}

Berdasarkan dari hasil análisis terhadap kondisi yang dijumpai dalam penelitian seperti dibahas dalam bab sebelumnya, maka kesimpulan yang dapat ditarik dalam penelitian ini adalah sebagai berikut :

(1). Secara umum pegawai Rumah Sakit Baptis Batu sudah memahami makna Penganggaran Berbasis Kinerja, yaitu penganggaran yang berorientasi pada output kinerja yang dihasilkan.

(2). Penganggaran Berbasis Kinerja, di Rumah Sakit Baptis Batu melaksanakan dengan arah dan tujuan yang jelas, karena : (a). Pada tahap perencanaan kinerja, rencana kerja dibuat dulu yang dihubungkan dengan Rencana Strategis. Rencana belanja diawali dengan pembuatan target pendapatan. (b). Pada tahap pelaksanaan anggaran, setiap bulan ditampilkan pencapaian kinerja unit masing-masing didalam grafik yang jelas dan dievaluasi bersama-sama dan saling berkoordinasi dengan unit terkait. (c). Pengukuran kinerja dilakukan dengan menghubungkan indicator output dan outcomes. (d). Pada tahap evaluasi, pencapaian kinerja dievaluasi dengan rencana strategis dan konsep value for Money. kontrol dan evaluasi berjalan efektif.

(3). Pada tahap pelaporan kinerja, menjadi bahan acuan untuk pembuatan anggaran tahun berikutnya (4). Kekuatan yang ditemukan dalam pelaksanaan Penganggaran Berbasis Kinerja di Rumah Sakit Baptis Batu yaitu: (a). Komunikasi yang berupa arahan manajemen, sosialisasi/pelatihan. (b). Sistem aplikasi yang terintegrasi dapat membantu control dan evaluasi. (c). Sistem reward dan punishment atas pencapaian kinerja. (d). Etika kerja yang jelas sehingga tupoksi, SPM dan SOP didalam pencapaiannya dapat berjalan.

Anggaran berbasis kinerja mempengaruhi kebudayaan pelaksana organisasi yang mengarah ke tujuan yang positif yang berdampak pada (1). Budaya karyawan yang berorientasi pelayanan kepada konsumen.

(2). Pengaruh atas efesiensi organisasi yang berdampak pada meningkatnya pendapatan dan efesiensi di biaya.

Adapun saran yang dapat diajukan peneliti sebagai hasil dari penelitian ini adalah sebagai berikut: (1). Pelaksanaan Penganggaran Berbasis Kinerja telah dipakai dan perlu penyempurnaan menuju arah yang lebih baik oleh Rumah Sakit Baptis Batu. (2). Komitmen dan arahan dari pimpinan di semua level dan peningkatan kemampuan pimpinan didalam anggaran berbasis kinerja untuk terus disempurnakan dan mereview dengan kebutuhan yang diperlukan oleh RSBB. (2). Kendala-kendala tentang perhitungan gaji, bonus dan insentif juga terus diperbaiki untuk mencapai kepuasan bagi pegawai. (3). Implementasikan sistem aplikasi komputer yang terintegrasi antara perencanaan, pelaksanaan dan pelaporan membuat proses monitoring dan evaluasi menjadi lebih cepat dan akurat. (4). Sistem pemberian reward (penghargaan) / punishment (sanksi) atas pencapaian kinerja dalam pelaksanaan anggaran lebih disempurnakan.

\section{Keterbatasan penelitian}

Penelitian ini terbatas waktu penelitiannya sehingga proses didalam pengesahan anggaran ke Yayasan Rumah Sakit Baptis Batu tidak dapat terlihat tanpa mengurangi tingkat validasi kebenarannya. Penelitan ini bersifat studi yang tidak dapat dibandingkan dengan kasus dan tempat yang berbeda. 


\section{DAFTAR PUSTAKA}

Bambang Sancoko, 2008, "Kajian terhadap Penganggaran Berbasis Kinerja di Indonesia", Badan Pendidikan dan Pelatihan Keuangan, Departemen Keuangan RI Buku Pedoman Reformasi Perencanaan dan Penganggaran, 2009.

Departemen Kesehatan Republik Indonesia, 2008, Buku Pedoman Penyelenggaraan Pelayanan Di Rumah Sakit, Jakarta.

Durahman, 2006, "Analisis Proses Penyusunan Anggaran Berbasis Kinerja", Dinas Kesahatan Jambi. Universitas Gadjah Mada

Edwards , George C. III, 1980, Implementing Public Policy, Washington DC:Congresional, Quartely Press.

Grizzle, Gloria A. and Carole D. Pettijohn, 2002, "Implementing Performance-Based Program Budgeting: A System-Dynamic Perspective", Public Administration Review, Jan/Feb 2002;62,1.

Haryanto, Sahmuddin, Arifuddin, 2007, Akuntansi Sektor Publik, Semarang: BadanPenerbit Universitas Diponegoro.

Indra Bastian, 2006, Akuntansi Sektor Publik, Jakarta: Erlangga.

Moleong, 2007, Metodologi Penelitian Kualitatif, Bandung: Remaja Rosdakarya.

Osborne, David and Ted Gaebler, 1995, Reinventing Government: How TheEntrepreneurial Spirit Is Tranforming The Public Sector, New York: Penguin Books Inc.

Peraturan Pemerintah Nomor 23 Tahun 2005 tentang pengelolaan Keuangan Badan Layanan Umum

Robinson, Marc, 2002, "Best Practices in Performance Budgeting", Discussion Paper, No. 124 Nopember 2002, Queensland University of Technology
Schick,A., "Twenty five Years of Budgeting Reform", OECD Journal on Budgeting, Vol 4 No.1 Th 2004.

Renstra Rumah Sakit Baptis, 2013.

Siregar, Ch. J.P., dan Amalia, L., 2004, Farmasi Rumah Sakit, Teori dan Penerapan, 25 49, Penerbit Buku Kedokteran EGC, Jakarta.

Sri Rahayu, 2007, "Studi Fenomenologis terhadap Proses Penyusunan Anggaran Daerah (Bukti Empiris dari Satu Satuan Kerja Perangkat Daerah di Propinsi Jambi)", Simposium Nasional Akuntansi $X$.

Sugiyono, 2008, Memahami Penelitian Kualitatif, Bandung: Alfabeta.

UU No. 44 Tahun 2009 tentang aturan Rumah Sakit.

Wang, XiaoHu, 1999, "Conditions to implement outcome-oriented performance budgeting: some empirical evidence", Journal of Public Budgeting, Accounting\& Financial Management, Winter 1999;11,4 